\title{
Atmospheric Methane Condition over the South Sumatera Peatland during the COVID-19 Pandemic
}

Aerosol and Air Quality Research

\section{OPEN ACCESS}

Received: March 30, 2021

Revised: June 11, 2021

Accepted: June 16, 2021

${ }^{*}$ Corresponding Authors:

Muhammad Rendana muhrendana@ft.unsri.ac.id Wan Mohd Razi Idris razi@ukm.edu.my

\section{Publisher:}

Taiwan Association for Aerosol Research

ISSN: $1680-8584$ print

ISSN: 2071-1409 online

\section{Copyright: The Author(s).}

This is an open access article distributed under the terms of the Creative Commons Attribution License (CC BY 4.0), which permits unrestricted use, distribution, and reproduction in any medium, provided the original author and source are cited

\author{
Muhammad Rendana ${ }^{1^{*}}$, Wan Mohd Razi Idris ${ }^{2 *}$, Sahibin Abdul Rahim ${ }^{3}$ \\ ${ }^{1}$ Department of Chemical Engineering, Faculty of Engineering, Universitas Sriwijaya, Indralaya \\ 30662 Sumatra Selatan, Indonesia \\ ${ }^{2}$ Department of Earth Sciences and Environment, Faculty of Science and Technology, Universiti \\ Kebangsaan Malaysia, 43600 Bangi, Selangor, Malaysia \\ ${ }^{3}$ Environmental Science Program, Faculty of Science and Natural Resources, Universiti Malaysia \\ Sabah, 88400 Kota Kinabalu, Sabah, Malaysia
}

\section{ABSTRACT}

Recent anthropogenic activities have degraded peatlands, the largest natural reservoir of soil carbon, thereby reducing their carbon uptake from the atmosphere. As one of the primary sources of methane $\left(\mathrm{CH}_{4}\right)$ emissions in terrestrial ecosystems, peatlands also contribute to atmospheric greenhouse gases. During the coronavirus disease 2019 (COVID-19) pandemic, Indonesia implemented a lockdown referred to as large-scale social restrictions (LSSR) in areas with high case numbers. To evaluate the effects of anthropogenic activity on peatlands, we investigated the $\mathrm{CH}_{4}$ concentrations in the atmosphere above the tropical peatlands of the Indonesian province South Sumatra before the LSSR (March 2020), during the LSSR (May 2020), and during the corresponding months of the previous year (March and May 2019). Using satellite-retrieved data from NASA, viz., the $\mathrm{CH}_{4}$ concentration and gross primary production (GPP) measured by the Atmospheric Infrared Sounder (AIRS) on board Aqua and Moderate Resolution Imaging Spectroradiometer (MODIS) on board Terra, respectively, we discovered a decrease of approximately $5.5 \%$ in the mean $\mathrm{CH}_{4}$ concentration (which averaged $1.73 \mathrm{ppm}$ across the periods prior to lockdown) as well as an increase in the GPP (which ranged from 53.3 to $63.9 \mathrm{~g} \mathrm{C} \mathrm{m}^{-2} \mathrm{day}^{-1}$ during the lockdown, indicating high atmospheric carbon intake) during the LSSR. Thus, the restrictions during lockdown, which reduced anthropogenic activities, such as land use conversion and biomass burning, and related events, such as peatland and forest fires, significantly influenced the level of atmospheric $\mathrm{CH}_{4}$ above the peatlands in Indonesia.

Keywords: Atmospheric $\mathrm{CH}_{4}$, COVID-19, Gross primary production, LSSR, Peatland

\section{INTRODUCTION}

Methane $\left(\mathrm{CH}_{4}\right)$ is a greenhouse gas which leads to global warming event and its impact is greater than carbon dioxide $\left(\mathrm{CO}_{2}\right)$ approximately 28-fold (Peng et al., 2016; Knoblauch et al., 2018). Globally, natural peatlands emit around $115 \mathrm{Tg} \mathrm{CH}_{4} \mathrm{y}^{-1}$ and it was believed as a major source of $\mathrm{CH}_{4}$ in the atmosphere (Nilsson et al., 2001). Peatlands cover about $3 \%\left(4 \times 106 \mathrm{~km}^{2}\right)$ of the land area of the earth and store a third of the world's soil carbon (Zhou et al., 2017; Lees et al., 2018). This large reservoir of carbon can affect the atmospheric $\mathrm{CH}_{4}$ level and changed the atmospheric greenhouse gases of the earth. To date, many peatlands have encountered degradation through anthropogenic activities such as grazing, draining, burning, and conversion to agriculture, industries, and urban areas, which reduce carbon uptake from the atmosphere (Waddington et al., 2010). Therefore, $\mathrm{CH}_{4}$ emissions from peatlands have taken interest from many researchers all over the world recently (Leroy et al., 2017; Saraswati and Strack, 2019; Huang et al., 2020).

The South Sumatran peatland which is located in the southeast of the island of Sumatra is known as one of the largest tropical peatlands in Indonesia. It covers an area of 1.42 million ha 
(Tampubolon et al., 2019) that encompasses the South Sumatra province of Indonesia at altitudes 2-33 $\mathrm{m}$ above sea level. This area is a notable and susceptible peatland that largely drives climate change in the Southeast Asian region. The $\mathrm{CH}_{4}$ field measurement methods are usually restricted by time and area scales, and cost, but by using the satellite remote sensing method, we can obtain atmospheric $\mathrm{CH}_{4}$ data over large areas rapidly and at a low cost. Satellites NASA Aqua, GOSAT, and Landsat have been employed in many studies of terrestrial $\mathrm{CH}_{4}$ emission over wetlands and other ecosystems (Akumu et al., 2010; Parker et al., 2018; Abed, 2020; Yang and Wang, 2020).

Furthermore, several studies regarding air pollutants' status during the COVID-19 pandemic have been extensively studied such as $\mathrm{NO}_{2}$ (Biswal et al., 2020), $\mathrm{SO}_{2}$ (Otmani et al., 2020), $\mathrm{CO}$ (Nadzir et al., 2020), $\mathrm{PM}_{10}$, and $\mathrm{PM}_{2.5}$ (Hashim et al., 2020). However, the atmospheric $\mathrm{CH}_{4}$ condition during the COVID-19 pandemic, especially in the lockdown period, was still sparse. Pachecho et al. (2020) found a major air pollutant such as $\mathrm{NO}_{2}$ decreased by $23 \%$ during the lockdown in Ecuador. This decrease could be due to human activities such as industrial, transportation, and commercial places were largely restricted (Rendana, 2020).

Previous studies by Fang et al. (2013) found high methane mole fractions in the air were recorded in Lin'an, China, which ranged from 0.032 to 0.196 ppm. Verhulst et al. (2017) have revealed atmospheric $\mathrm{CH}_{4}$ concentration was very variable over Los Angeles, ranging from 0.08 to $0.15 \mathrm{ppm}$ in 2015. The atmospheric $\mathrm{CH}_{4}$ emissions are generally affected by vegetation types, climate, and land use (Pelletier et al., 2007). Although $\mathrm{CH}_{4}$ fluxes in the South Sumatran peatland have been studied (Prayitno et al., 2019), information on the impact of the COVID-19 pandemic on the atmospheric $\mathrm{CH}_{4}$ status over the peatlands is still sparse.

In the current study, atmospheric $\mathrm{CH}_{4}$ over the tropical peatlands in the South Sumatra province was measured in three different periods such as before lockdown (referred to as large-scale social restrictions [LSSR] in Indonesia), during the lockdown and last year data in 2019. The gross primary production (GPP) value was also examined to understand factors that govern $\mathrm{CH}_{4}$ fluxes in the peatland. The aim of this study was to analyze the atmospheric $\mathrm{CH}_{4}$ condition in the South Sumatran peatland during the COVID-19 pandemic.

\section{METHODS}

\subsection{Study Site}

The study site is in the South Sumatra province that surrounded by peatland ecosystems (Fig. 1). It is located in the southeast of the main island of Sumatra $\left(2^{\circ} 45^{\prime} \mathrm{S}, 103^{\circ} 50^{\prime} \mathrm{E}\right)$ and covers about $91,592 \mathrm{~km}^{2}$. In general, the total peatland area of Indonesia is around 20.6 million ha and $35 \%$ of the peatlands are situated in the island of Sumatra (Wahyunto and Suparto, 2005). In South Sumatra, peatland areas are classified based on the level of peat maturity such as fibric, hemic, and sapric (Kirana et al., 2016). These areas are found from very shallow peat $(0.5-1 \mathrm{~m})$ to very deep peat ( $>5 \mathrm{~m}$ ) (Setiawan et al., 2015). The major land uses found in the peatland are consisted of agricultural activities such as oil palm, rice, rubber, and horticulture. The land use conversion has resulted in a number of hotspots in the peatland areas which increase from year to year. For instance, the hotspot frequency records around 18,852 in 2006 and continues to increase to 26,193 hotspots in 2014. The peatland fire events have contributed to greenhouse gas emissions such as $\mathrm{CO}_{2}, \mathrm{CH}_{4}$, and nitrous oxide $\left(\mathrm{N}_{2} \mathrm{O}\right)$ to the atmosphere. These areas are one of the haze contributors in the Southeast Asian region.

\subsection{Spatial Distribution of $\mathrm{CH}_{4}$ in Atmosphere}

Satellite retrieval of the trace gas data was applied to estimate the air quality distribution. $\mathrm{CH}_{4}$ mole fraction in the air was measured by Atmospheric Infrared Sounder (AIRS) aboard NASA's Aqua satellite at $1^{\circ} \times 1^{\circ}$ resolution. In this study, we used the AIRS/Aqua daily data product (AIRS3STD V006). The AIRS used 3D analysis of the atmospheric column along with trace gases, cloud, and surface properties. The $\mathrm{CH}_{4}$ mole fraction in air data was obtained from NASA's website (https://giovanni.gsfc.nasa.gov/giovanni/). We chose the $\mathrm{CH}_{4}$ mole fraction data in several study periods such as before the LSSR (March 2020), during the LSSR (May 2020), and the last year's data in 2019 (March and May 2019). Then, we cropped the area of interest and downloaded the 


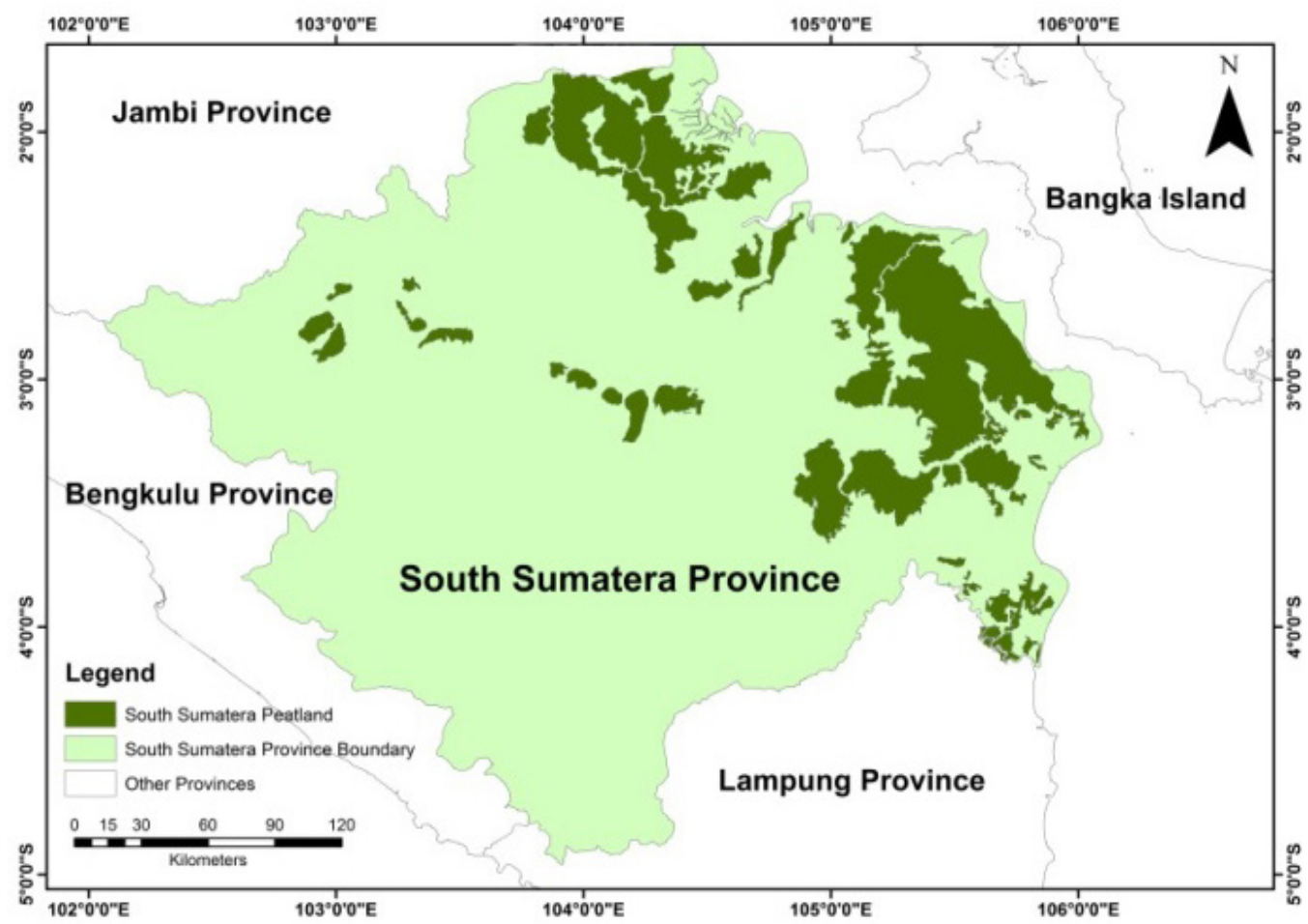

Fig. 1. The location of study area.

data within the area. The format data of files downloaded were in the form of images (TIFF). Then, the $\mathrm{CH}_{4}$ raw data were processed using ArcGIS software before they could be used for this study. Several important processes were carried out included resample, interpolation, and reclassify the data. In this study, the $\mathrm{CH}_{4}$ data from satellites were validated against the air quality monitoring system (AQMS) that was organized by the Ministry of Environment and Forestry of the Republic of Indonesia. The validation results showed a good accuracy between the satellite data and the ground-level data with $\mathrm{R}^{2}=0.86$, $\mathrm{RMSE}=0.10$, and $\mathrm{MAE}=0.07$. The high accuracy result between the satellite data and the ground-level data indicated the satellite data from the AIRS sensor could be used for this study.

\subsection{GPP Estimation}

The Moderate Resolution Imaging Spectroradiometer (MODIS)/Terra GPP (MOD17A2H) product is publicly available and ready-calculated; thus, it was used in this study for assessing the GPP in the study area. Qiu et al. (2020) have found that the MOD17A2H product had a good agreement with the GPP of flux towers over their forest sites in North America. The MOD17A2H GPP was computed using the light use efficiency (LUE) model proposed by Monteith (1977). The formula for this model was shown in Eq. (1).

$G P P=f P A R \times P A R \times \varepsilon$

The fPAR is the fraction of photosynthetically active radiation absorbed by the plant, the PAR is the total photosynthetically active radiation event on the plant and $\varepsilon$ is the conversion efficiency of the absorbed energy to the fixed carbon. The formula above has been adopted in NASA's MODIS that allowed scientists to quantify the metabolism of the earth on a daily basis. Therefore, in this study, the GPP data were measured by MODIS aboard the Terra spacecraft at $500 \mathrm{~m} \times 500 \mathrm{~m}$ resolution. The data were a cumulative 8-day composite of values based on the radiation use efficiency concept that could be potentially used as inputs to data models to calculate terrestrial energy, carbon, water cycle processes, and biogeochemistry of vegetation. In general, the GPP was the technical term for plant photosynthesis. The high GPP value indicated areas where plants used a higher amount of carbon, while the low GPP indicate areas with a lower amount of carbon 
absorbed. The GPP data were then analyzed at the same periods with atmospheric $\mathrm{CH}_{4}$ to give a better understanding of $\mathrm{CH}_{4}$ fluxes from the peatland. In this study, the GPP maps were validated against the land cover map obtained from the Department of Forestry of Indonesia. The validation results obtained a good accuracy between the GPP map and the land cover map with $R^{2}=0.90$, RMSE $=0.09$, and MAE $=0.06$. Therefore, the GPP data from the MODIS sensor was suitable to be applied for this study.

\section{RESULTS AND DISCUSSION}

\subsection{Atmospheric $\mathrm{CH}_{4}$ Concentration over the South Sumatran Peatland}

Before the LSSR period in March 2020, the mean concentration for $\mathrm{CH}_{4}$ over the study area was about 1.82 ppm (Fig. 2(c)). The highest concentration was observed in the northern peatlands. In March and May 2019, our study found about a 6\% increase in $\mathrm{CH}_{4}$ concentration over the peatland areas compared with during the same period in 2020 (Figs. 2(a-b)). Fig. 3 showed the monthly average concentrations for $\mathrm{CH}_{4}$ in 2019 were higher than the concentrations in 2020 . The high concentration of $\mathrm{CH}_{4}$ in 2019 could be caused by the intensive anthropogenic activities during this period. According to Fig. 3, we found a significant increase in $\mathrm{CH}_{4}$ concentration after June in both years. It might be due to the beginning of the dry season (May-August). During this period, this area frequently experienced forest fire events, especially peatland fires. These events have contributed to high greenhouse gas emissions $\left(\mathrm{CO}_{2}\right.$ and $\left.\mathrm{CH}_{4}\right)$ to the atmosphere. A recent
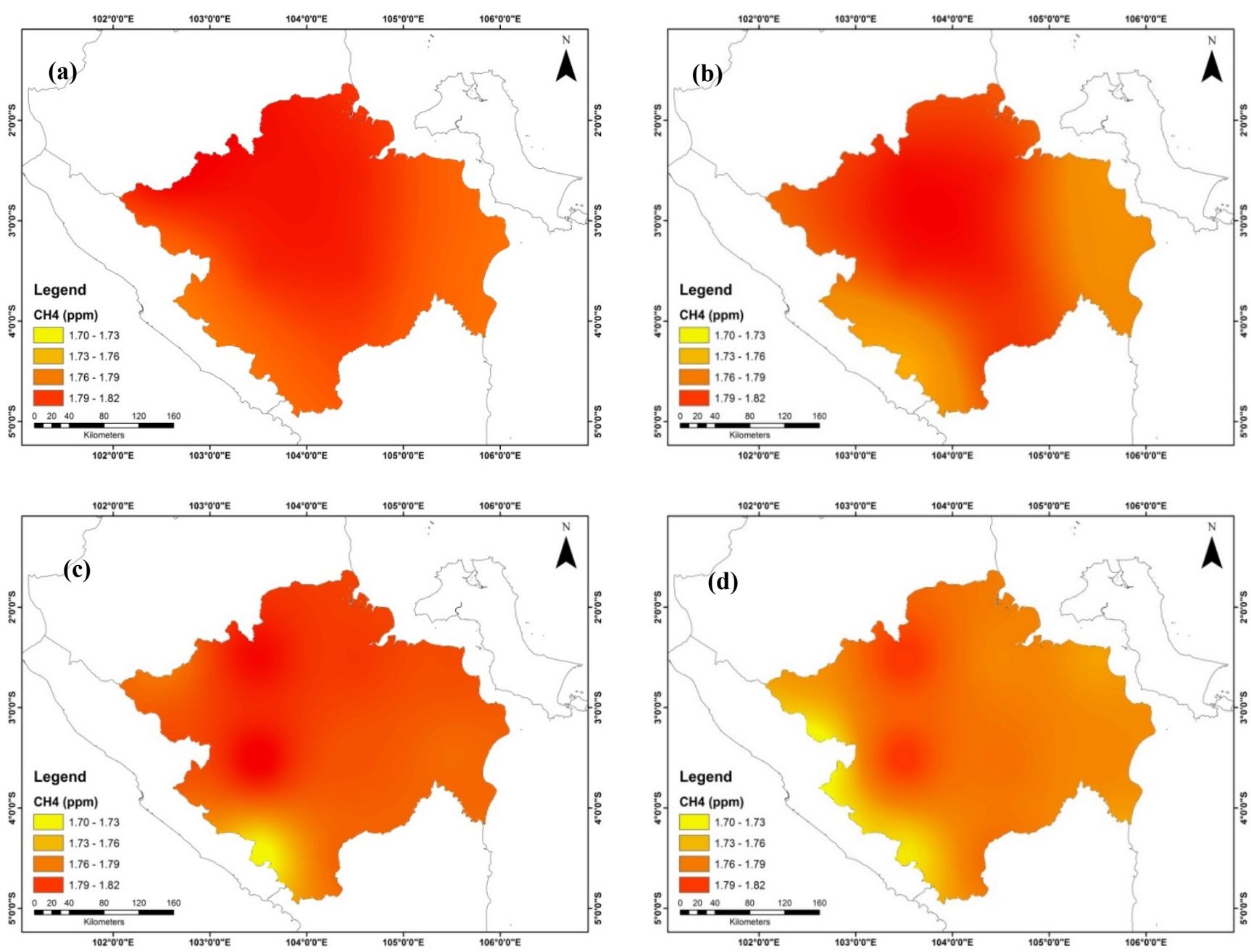

Fig. 2. Atmospheric $\mathrm{CH}_{4}$ concentrations before COVID-19 pandemic (a) in March 2019, (b) in May 2019, (c) before the LSSR in March 2020, and (d) during the LSSR in May 2020 in the study area. 


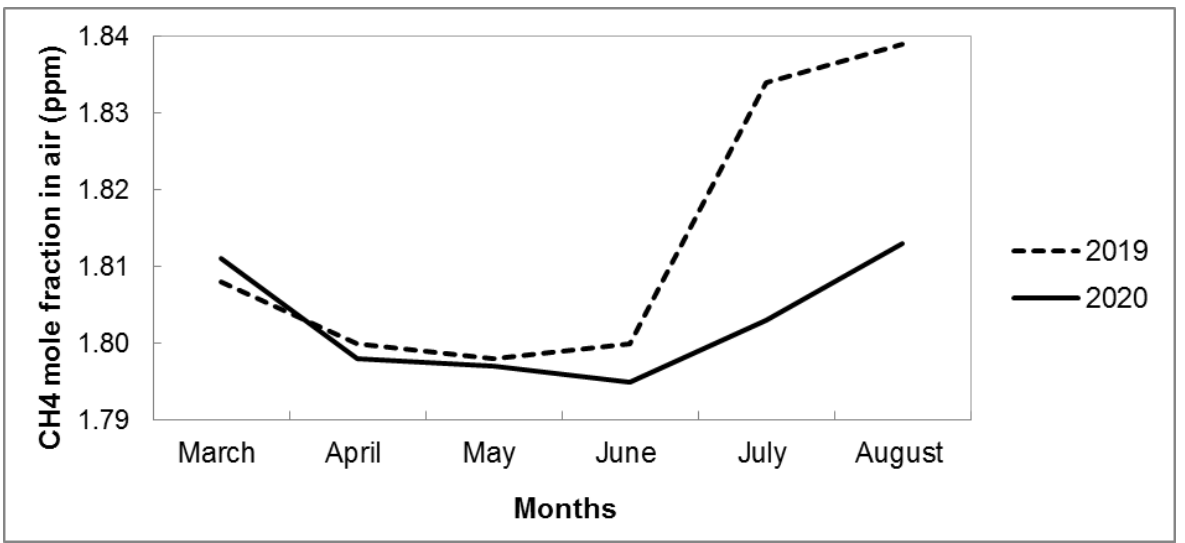

Fig. 3. Monthly concentration of atmospheric $\mathrm{CH}_{4}$ over the South Sumatran peatland before COVID-19 pandemic (dashed line) and during COVID-19 pandemic (solid line) periods.

study has discovered that in Sumatra, the deforestation hotspots were mostly found in southern areas (Singh and Yan, 2021). The majority of hotspots took place in areas with greater human activities.

If we compared with other studies, our results were slightly higher than $\mathrm{CH}_{4}$ monthly means of 1.74 ppm in western China (Zhou et al., 2004). Furthermore, a study by Thompson et al. (2018) has found a higher atmospheric $\mathrm{CH}_{4}$ concentration of about $1.82 \mathrm{ppm}$ in tropics and subtropics. Based on their assumption, the concentration of $\mathrm{CH}_{4}$ was strongly influenced by an increase in microbial and fossil fuel emissions. The changes in the microbial emissions were in line with the wetland source responding to variation in precipitation.

There was a notable decrease of $\mathrm{CH}_{4}$ in the study area from April to June 2020; this was due to the COVID-19 pandemic and mitigation action at those times. Moreover, in natural conditions, the deep peat could be one of the main contributors to the higher emission of $\mathrm{CH}_{4}$ from the peatlands. In the study area, the deepest-peat ( $>5 \mathrm{~m}$ ) areas were more distributed in the northern peatland thus make these areas possibly emitted a high $\mathrm{CH}_{4}$ emission. Also, agricultural lands situated around the peatland such as oil palm, rubber, and rice could add $\mathrm{CH}_{4}$ emissions to the atmosphere (Yulianingsih, 2016). During normal days before the LSSR, anthropogenic activities were intensively carried out in the study area especially in the northern peatlands. These activities included land use conversion from swamp or secondary forests to oil palm, rubber, rice fields, and freshwater fisheries. Converting from secondary forest peatland to agricultural lands tended to increase emissions of $\mathrm{CH}_{4}$ (58.3\%) and $\mathrm{CO}_{2}$ (25\%) to the atmosphere (Inubushi et al., 2003). Additionally, in studies of $\mathrm{CH}_{4}$ fluxes from drained and deforested peatlands, the $\mathrm{CH}_{4}$ uptake (2.5 $\mathrm{mg} \mathrm{m}^{-2}$ day ${ }^{-1}$ ) was significantly lower than the $\mathrm{CH}_{4}$ uptake in the undisturbed peatlands (5.6 $\mathrm{mg} \mathrm{m}^{-2}$ day $^{-1}$ ) (Sun et al., 2011; Salm et al., 2012).

During the LSSR period, the concentration of $\mathrm{CH}_{4}$ was found to drop at most of the peatland areas. The mean $\mathrm{CH}_{4}$ concentration reduced to 5.5\%. Fig. 2(d) illustrated the spatial distribution of $\mathrm{CH}_{4}$ over the study area during the LSSR period. The northeastern peatlands recorded the lowest concentration among peatland areas that was around $1.72 \mathrm{ppm}$. This result indicated that the restriction of major anthropogenic activities attributed to the reduction of $\mathrm{CH}_{4}$ levels over the peatland areas. In summary, we assumed the percentage reduction of $\mathrm{CH}_{4}$ level during the LSSR in the peatland areas was quite significant. This was because, in another study by Chauhan and Singh (2020), they found the $\mathrm{CH}_{4}$ level decreased only by $0.54 \%$ as compared with before lockdown period in India.

Furthermore, we revealed the highest decrease in $\mathrm{CH}_{4}$ level was observed in the south and southwest of South Sumatra. There was a possible reason for this condition; it might be due to the effect of meteorological factors such as wind direction and velocity. From February to May, the wind pattern in this region mostly blew from the northeast to the southeast that might affect the diffusion of $\mathrm{CH}_{4}$ gaseous in the study area. A previous study by Battista and de Lieto Vollaro (2017) has found a strong association between major air gaseous pollutants with wind direction and speed, air temperature, and solar radiation in Italy. 


\subsection{GPP Values over the South Sumatran Peatland}

The spatial distribution of the monthly average GPPs before the LSSR (March 2020), during the LSSR (May 2020), and last year's data (March and May 2019) was shown in Fig. 4. The highest GPP values were recorded in the LSSR period at the northwestern peatlands $\left(63.9 \mathrm{~g} \mathrm{C} \mathrm{m}^{-2}\right.$ day $\left.^{-1}\right)$ while lower values at the northern and northeastern peatlands $\left(53.3 \mathrm{~g} \mathrm{C} \mathrm{m}^{-2} \mathrm{day}^{-1}\right.$ ) (Fig. 4 (d)). It would explain why we obtained the low $\mathrm{CH}_{4}$ concentration in the atmosphere during the LSSR period; this was due to the high carbon uptake in the study area. To approve this assumption, we run the regression analysis to analyze the association between $\mathrm{CH}_{4}$ and GPP values as shown in Fig. 5. Our analysis showed the $\mathrm{CH}_{4}$ and GPP values had good accuracy with $\mathrm{R}^{2}=0.89$.

The lowest GPP values were observed in the period before the LSSR and last year 2019 data; the GPP values varied from 0 to $20.9 \mathrm{~g} \mathrm{C} \mathrm{m}^{-2}$ day $^{-1}$ at most of the peatlands (Figs. 4(a-c)). The results were slightly higher than the GPP values of peatlands in the Kalimantan, Indonesia, which were just ranged from 4.62 to $41.09 \mathrm{~g} \mathrm{C} \mathrm{m}^{-2}$ day $^{-1}$ (Wang et al., 2014). However, in the Canadian peatlands, the GPP values were found much lower, which ranged from 5.0 to $8.5 \mathrm{~g} \mathrm{C} \mathrm{m}^{-2}$ day $^{-1}$. This was because the GPP was dropped to zero in winter due to snow cover and low temperatures decreased photosynthesis to zero. The GPP in the subtropical peatlands started to rise as the snow ended which occurred in early April (Lafleur et al., 2003). The GPP values could be associated with the weather condition (Bubier et al., 2003). However, based on the previous study, the statistical proof found that the GPP value in a peatland was not statistically significant with $p=$ 0.706 (Connolly et al., 2009). Therefore, the uncertainty of the weather condition effect on the GPP value in a peatland had little effect.
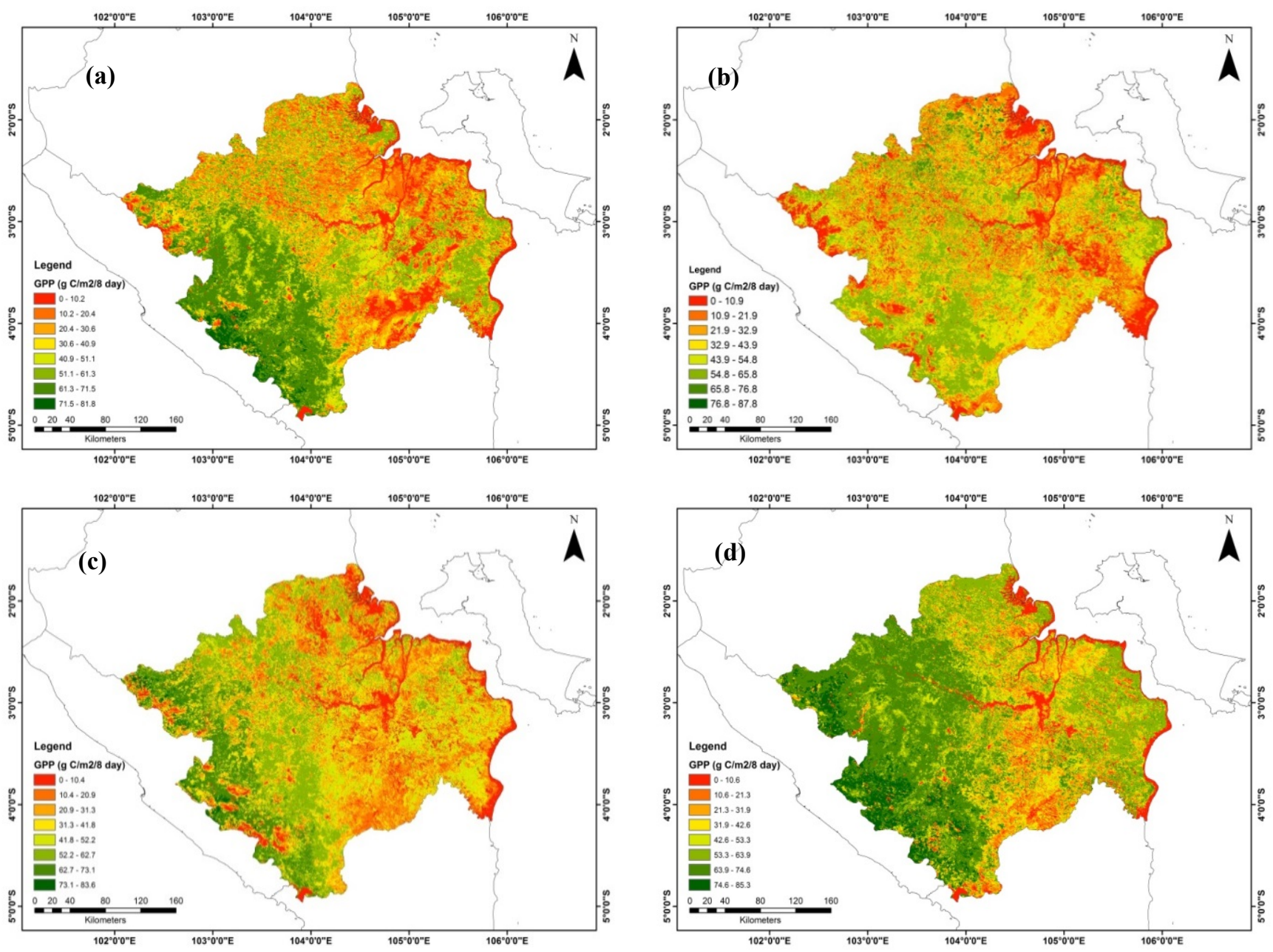

Fig. 4. The GPP values before COVID-19 pandemic (a) in March 2019, (b) in May 2019, (c) before the LSSR in March 2020, and (d) during the LSSR in May 2020 in the study area. 


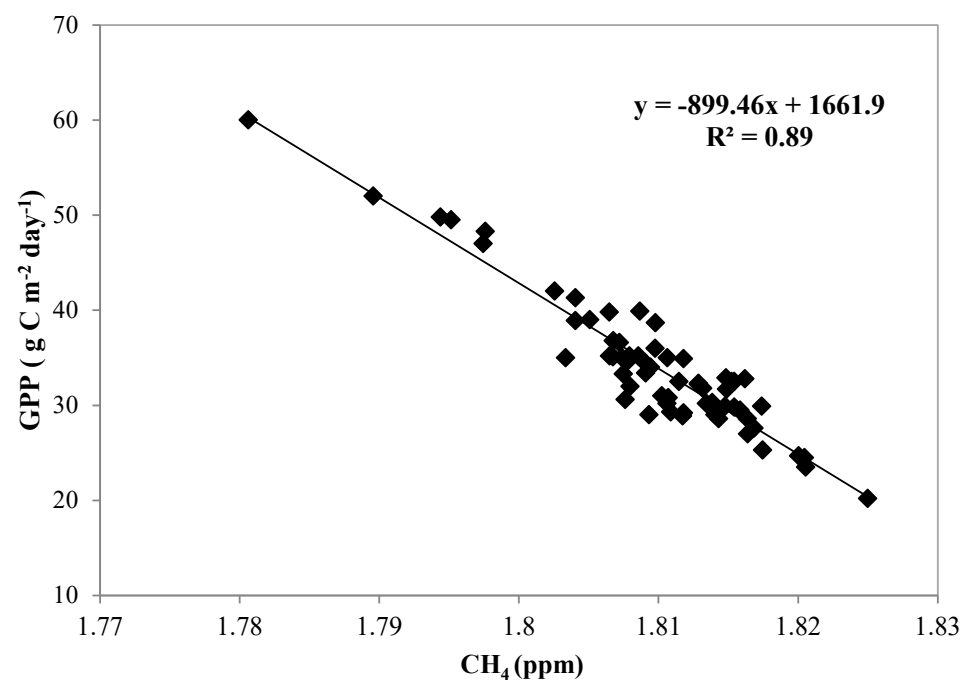

Fig. 5. The relationship between the GPP and $\mathrm{CH}_{4}$ values.

In tropical peatlands like the study area, the decrease carbon uptake was more caused by the deforestation of vegetation in the peatland thus make the low photosynthetic activity to capture carbon in the air. The GPP was reduced to zero in March and May 2019, and March 2020 (before the LSSR periods) because many vegetated areas have been deforested; thus, it made low temperatures which reduced photosynthesis to zero. During those periods, human activities were intensively carried out which has degraded the peatlands but when the social restriction policy was implemented due to the COVID-19 outbreak, it has improved GPP values in all peatland areas. Another reason, previous studies found that the fPAR from the satellite data could capture GPP well in the growing season from May to October (Wang et al., 2014). Based on our observation, we also found the same result when we found high GPP values in May 2020, while low values observed in March 2020. The high temperature in the area in this early year was believed to accelerate the rate of methanogenesis and this was an impact of raising an ebullition frequency in the peatlands (Schubert et al., 2012).

\section{CONCLUSIONS}

We analyzed the effect of the COVID-19-related LSSR on the $\mathrm{CH}_{4}$ concentrations in the atmosphere above the peatlands of South Sumatra. The mean concentration, which averaged 1.73 ppm before the LSSR, fell by 5.5\% during May 2020. This decrease in the $\mathrm{CH}_{4}$ was driven by the increase in the total carbon uptake of the study area, represented by the GPP, which peaked during the LSSR. As anthropogenic activities, such as land cover conversion, biomass burning, and agricultural activities, are primarily responsible for the rise in $\mathrm{CH}_{4}$ emissions from peatlands, the restrictions during lockdown led to lower levels of atmospheric $\mathrm{CH}_{4}$ in this region. Our results may assist in formulating a policy for mitigating such emissions in peatland areas.

\section{REFERENCES}

Abed, F.G. (2020). Spatiotemporal observations of $\mathrm{CH}_{4}$ and $\mathrm{CO}_{2}$ over Iraq using Atmospheric Infrared Sounder (AIRS) data. J. Apl. Adv. Res. 5, 6-10. https://doi.org/10.21839/jaar.2020.v5.324

Akumu, C.E., Pathirana, S., Baban, S., Bucher, D. (2010). Modeling methane emission from wetlands in North-Eastern new South Wales, Australia using Landsat ETM+. Remote Sens. 2, 1378-1399. https://doi.org/10.3390/rs2051378

Battista, G., de Lieto Vollaro, R. (2017). Correlation between air pollution and weather data in urban areas: Assessment of the city of Rome (Italy) as spatially and temporally independent regarding pollutants. Atmos. Environ. 165, 240-247. https://doi.org/10.1016/j.atmosenv.2017. 06.050 
Biswal, A., Singh, T., Singh, V., Ravindra, K., Mor, S. (2020). COVID-19 lockdown and its impact on tropospheric $\mathrm{NO}_{2}$ concentrations over India using satellite-based data. Heliyon 6, e04764. https://doi.org/10.1016/j.heliyon.2020.e04764

Bubier, J.L., Bhatia, G., Moore, T.R., Roulet, N.T., Lafleur, P.M. (2003). Spatial and temporal variability in growing-season net ecosystem carbon dioxide exchange at a large peatland in Ontario, Canada. Ecosystems 1, 353-367. https://doi.org/10.1007/s10021-003-0125-0

Chauhan, A., Singh, R.P. (2021). Effect of lockdown on HCHO and Trace gases over India during March 2020. Aerosol Air Qual. Res. 21, 200445. https://doi.org/10.4209/aaqr.2020.07.0445

Connolly, J., Roulet, N.T., Seaquist, J.W., Holden, N.M., Lafleur, P.M., Humphreys, E.R., Ward, S.M. (2009). Using MODIS derived f PAR with ground based flux tower measurements to derive the light use efficiency for two Canadian peatlands. Biogeosciences 6, 225-234. https://doi.org/10. 5194/bg-6-225-2009

Fang, S.X., Zhou, L.X., Masarie, K.A., Xu, L., Rella, C.W. (2013). Study of atmospheric $\mathrm{CH}_{4}$ mole fractions at three WMO/GAW stations in China. J. Geophys. Res. 118, 4874-4886. https://doi.org/10.1002/jgrd.50284

Hashim, B. M., Al-Naseri, S. K., Al-Maliki, A., Al-Ansari, N. (2020). Impact of COVID-19 lockdown on $\mathrm{NO}_{2}, \mathrm{O}_{3}, \mathrm{PM}_{2.5}$ and $\mathrm{PM}_{10}$ concentrations and assessing air quality changes in Baghdad, Iraq. Sci. Total Environ. 754, 141978. https://doi.org/10.1016/j.scitotenv.2020.141978

Huang, X., Silvennoinen, H., Kløve, B., Regina, K., Kandel, T.P., Piayda, A., Höglind, M. (2020). Modelling $\mathrm{CO}_{2}$ and $\mathrm{CH}_{4}$ emissions from drained peatlands with grass cultivation by the BASGRABGC model. Sci. Total Environ. 1, 144385. https://doi.org/10.1016/j.scitotenv.2020.144385

Inubushi, K., Furukawa, Y., Hadi, A., Purnomo, E., Tsuruta, H. (2003). Seasonal changes of $\mathrm{CO}_{2}, \mathrm{CH}_{4}$ and $\mathrm{N}_{2} \mathrm{O}$ fluxes in relation to land-use change in tropical peatlands located in coastal area of South Kalimantan. Chemosphere 52, 603-608. https://doi.org/10.1016/S0045-6535(03)00242-X

Kirana, A.P., Sitanggang, I.S., Syaufina, L. (2016). Hotspot pattern distribution in peat land area in Sumatera based on spatio temporal clustering. Procedia Environ. Sci. 33, 635-645. https://doi.org/10.1016/j.proenv.2016.03.118

Knoblauch, C., Beer, C., Liebner, S., Grigoriev, M.N., Pfeiffer, E.M. (2018). Methane production as key to the greenhouse gas budget of thawing permafrost. Nat. Clim. Change 8, 309-312. https://doi.org/10.1038/s41558-018-0095-z

Lafleur, P.M., Roulet, N.T., Bubier, J.L., Frolking, S., Moore, T.R. (2003). Interannual variability in the peatland-atmosphere carbon dioxide exchange at an ombrotrophic bog. Global Biogeochem. Cycles 17, 1036. https://doi.org/10.1029/2002GB001983

Lees, K.J., Quaife, T., Artz, R.R.E., Khomik, M., Clark, J.M. (2018). Potential for using remote sensing to estimate carbon fluxes across northern peatlands-A review. Sci. Total Environ. 615, 857-874. https://doi.org/10.1016/j.scitotenv.2017.09.103

Leroy, F., Gogo, S., Guimbaud, C., Bernard-Jannin, L., Hu, Z., Laggoun-Défarge, F. (2017). Vegetation composition controls temperature sensitivity of $\mathrm{CO}_{2}$ and $\mathrm{CH}_{4}$ emissions and DOC concentration in peatlands. Soil Biol. Biochem. 107, 164-167. https://doi.org/10.1016/j.soilbi 0.2017.01.005

Monteith, J.L. (1977). Climate and the efficiency of crop production in Britain. Philos. Trans. R. Soc. 281, 277-294. https://doi.org/10.1098/rstb.1977.0140

Nadzir, M.S.M., Ooi, M.C.G., Alhasa, K.M., Bakar, M.A.A., Mohtar, A.A.A., Nor, M.F.F.M., Latif, M.T., Hamid, H.H.A., Ali, S.H.M., Ariff, N.M., Anuar, J., Ahamad, F., Azhari, A., Hanif, N.M., Subhi, M.A., Othman, M., Nor, M.Z.M. (2020). The impact of movement control order (MCO) during pandemic COVID-19 on local air quality in an urban area of Klang valley, Malaysia. Aerosol Air Qual. Res. 20, 1237-1248. https://doi.org/10.4209/aaqr.2020.04.0163

Nilsson, M., Mikkelä, C., Sundh, I., Granberg, G., Svensson, B.H., Ranneby, B. (2001). Methane emission from Swedish mires: National and regional budgets and dependence on mire vegetation. J. Geophys. Res. 106, 20847-20860. https://doi.org/10.1029/2001JD900119

Otmani, A., Benchrif, A., Tahri, M., Bounakhla, M., El Bouch, M., Krombi, M.H. (2020). Impact of Covid-19 lockdown on $\mathrm{PM}_{10}, \mathrm{SO}_{2}$ and $\mathrm{NO}_{2}$ concentrations in Salé City (Morocco). Sci. Total Environ. 735, 139541. https://doi.org/10.1016/j.scitotenv.2020.139541

Pacheco, H., Díaz-López, S., Jarre, E., Pacheco, H., Méndez, W., Zamora-Ledezma, E. (2020). NO 2 levels after the COVID-19 lockdown in Ecuador: A trade-off between environment and human health. Urban Clim. 34, 100674. https://doi.org/10.1016/j.uclim.2020.100674 
Parker, R.J., Boesch, H., McNorton, J., Comyn-Platt, E., Gloor, M., Wilson, C., Bloom, A.A. (2018). Evaluating year-to-year anomalies in tropical wetland methane emissions using satellite $\mathrm{CH}_{4}$ observations. Remote Sens. Environ. 211, 261-275. https://doi.org/10.1016/j.rse.2018.02.011

Pelletier, L., Moore, T.R., Roulet, N.T., Garneau, M., Beaulieu-Audy, V. (2007). Methane fluxes from three peatlands in the La Grande Riviere watershed, James Bay lowland, Canada. J. Geophys. Res. Biogeosci. 112, G01018. https://doi.org/10.1029/2006JG000216

Peng, S., Piao, S., Bousquet, P., Ciais, P., Li, B., Lin, X., Zhou, F. (2016). Inventory of anthropogenic methane emissions in mainland China from 1980 to 2010. Atmos. Chem. Phys. 16, 1454514562. https://doi.org/10.5194/acp-16-14545-2016

Prayitno, M.B., Dunand, H., Sulistyani, D.P. (2019). Pengaruh Pupuk Urea dan Mineral Zeolit terhadap Emisi Karbondioksida $\left(\mathrm{CO}_{2}\right)$ pada Pertanaman Padi (Oryza Sativa L.) di Tanah Gambut [Effect of Urea Fertilizer and Zeolite Mineral on Carbon Dioxide $\left(\mathrm{CO}_{2}\right)$ Emissions in Rice (Oryza Sativa L.) Planting in Peat Soil]. In Proceedings of Lahan Suboptimal 1, 437-444.

Qiu, R., Han, G., Ma, X., Xu, H., Shi, T., Zhang, M. (2020). A comparison of OCO-2 SIF, MODIS GPP, and GOSIF data from gross primary production (GPP) estimation and seasonal cycles in North America. Remote Sens. 12, 258-266. https://doi.org/10.3390/rs12020258

Rendana, M. (2020). Impact of the wind conditions on COVID-19 pandemic: A new insight for direction of the spread of the virus. Urban Clim. 34, 100680. https://doi.org/10.1016/j.uclim.2 020.100680

Saraswati, S., Strack, M. (2019). Road crossings increase methane emissions from adjacent peatland. J. Geophys. Res. Biogeosci. 124, 3588-3599. https://doi.org/10.1029/2019JG005246

Schubert, P., Lagergren, F., Aurela, M., Christensen, T., Grelle, A., Heliasz, M., Eklundh, L. (2012). Modeling GPP in the Nordic forest landscape with MODIS time series data-comparison with the MODIS GPP product. Remote Sens. Environ. 126, 136-147. https://doi.org/10.1016/j.rse. 2012.08.005

Setiawan, B.I., Arief, C., Saptomo, S.K., Gunawan, A., Indriyanto, H. (2015). Estimating distribution of carbon stock in tropical peatland using a combination of an empirical peat depth model and GIS. Procedia Environ. Sci. 24, 152-157. https://doi.org/10.1016/j.proenv.2015.03.020

Singh, M., Yan, S. (2021). Spatial-temporal variations in deforestation hotspots in Sumatra and Kalimantan from 2001-2018. Ecol. Evol. 11, 7302-7314. https://doi.org/10.1002/ece3.7562

Sun, X., Mu, C., Song, C. (2011). Seasonal and spatial variations of methane emissions from montane wetlands in Northeast China. Atmos. Environ. 45, 1809-1816. https://doi.org/10.10 16/j.atmosenv.2011.01.019

Tampubolon, J., Aluyah, C., Heptiana, E. (2019). Persepsi masyarakat desa riding kabupaten ogan komering ilir terhadap upaya pencegahan kebakaran di lahan gambut [Perceptions of the riding village community, ogan komering ilir district on efforts to prevent fires on peatlands]. Sylva 7, 49-57.

Thompson, R.L., Nisbet, E.G., Pisso, I., Stohl, A., Blake, D., Dlugokencky, E.J., White, J.W.C. (2018). Variability in atmospheric methane from fossil fuel and microbial sources over the last three decades. Geophys. Res. Lett. 45, 11499-11508. https://doi.org/10.1029/2018GL078127

Verhulst, K.R., Karion, A., Kim, J., Salameh, P K., Keeling, R.F., Newman, S., Wong, C. (2017). Carbon dioxide and methane measurements from the Los Angeles Megacity Carbon ProjectPart 1: Calibration, urban enhancements, and uncertainty estimates. Atmos. Chem. Phys. 17, 8313-8341. https://doi.org/10.5194/acp-17-8313-2017

Waddington, J.M., Strack, M., Greenwood, M.J. (2010). Toward restoring the net carbon sink function of degraded peatlands: Short-term response in $\mathrm{CO}_{2}$ exchange to ecosystem-scale restoration. J. Geophys. Res. Biogeosci. 115, G01008. https://doi.org/10.1029/2009JG001090

Wahyunto, R.S., Suparto, S.H. (2005). Sebaran gambut dan kandungan karbon di Sumatera dan Kalimantan [Peat distribution and carbon content in Sumatra and Kalimantan]. Wetlands International-International Programmed a Wildlife Habitat Canada, Bogor.

Wang, J., Dong, J., Liu, J., Huang, M., Li, G., Running, S. W. and Liu, Y. (2014). Comparison of gross primary productivity derived from GIMMS NDVI3g, GIMMS, and MODIS in Southeast Asia. Remote Sens. 6, 2108-2133. https://doi.org/10.3390/rs6032108

Yang, Y., Wang, Y. (2020). Using the BFAST algorithm and multitemporal AIRS data to investigate variation of atmospheric methane concentration over Zoige Wetland of China. Remote Sens. 12, 3199. https://doi.org/10.3390/rs12193199 
Yulianingsih, E. (2016). Emisi methana $\left(\mathrm{CH}_{4}\right)$ dari saluran drainase lahan gambut di Kalimantan Tengah [Methane $\left(\mathrm{CH}_{4}\right)$ emissions from peatland drainage channels in Central Kalimantan]. Agric 28, 25-30. https://doi.org/10.24246/agric.2016.v28.i1.p25-30

Zhou, W., Cui, L., Wang, Y., Li, W. (2017). Methane emissions from natural and drained peatlands in the Zoigê, eastern Qinghai-Tibet Plateau. J. For. Res. 28: 539-547. https://doi.org/10.1007/ s11676-016-0343-x

Zhou, L.X., Worthy, D.E.J., Lang, P.M., Ernst, M.K., Zhang, X.C., Wen, Y.P., Li, J.L. (2004). Ten years of atmospheric methane observations at a high elevation site in Western China. Atmos. Environ. 38, 7041-7054. https://doi.org/10.1016/j.atmosenv.2004.02.072 